\title{
Oven Device
}

National Cancer Institute

\section{Source}

National Cancer Institute. Oven Device. NCI Thesaurus. Code C50092.

An enclosed structural device designed for heating an object. 